\title{
Penggunaan Media Pembelajaran Daring pada Masa Pandemi COVID-
} 19

\author{
1Siti Aisyah, ${ }^{2}$ Muhammad Alif Kurniawan \\ 1,2Pendidikan Agama Islam, Universitas Ahmad Dahlan \\ E-mail: 1 $\underline{\text { Siti1800031227@webmail.uad.ac.id ,2muh.kurniawan@pai.ac.id }}$
}

\begin{abstract}
Abstrak
Pandemi covid-19 telah telah mengubah tatanan hidup manusia dalam segala aspek kehidupan. Pemerintah melakukan pembatasan aktivitas masyarakat untuk mencegah kerumunan guna menghindari penyebaran covid-19. Berdasarkan Surat Edaran Nomor 15 Tahun 2020 tentang Pedoman Penyelenggaraan Belajar dari Rumah Dalam Masa Darurat Penyebaran Covid-19, pemerintah mengalihkan kegiatan belajar mengajar di kelas atau konvensional menjadi kelas daring atau virtual. Fenomena ini tentunya menjadi hal baru yang dialami pendidik dan peserta didik karena harus menggunakan media pembelajaran daring untuk menghubungkan satu sama lain. Penggunaan media pembelajaran daring selama pandemi covid-19 bisa menjadi alternatif pilihan untuk memberikan rasa aman dalam belajar mengajar. Banyak sekali media pembelajaran daring yang tersedia seperti Zoom, WhatsApp, Google Classroom, Google Meeting, Edmodo dan lainnya. Namun guru harus pintar dalam memilih media pembelajaran yang tepat sesuai peruntukannya dengan menimbang kesiapan dan kondisi siswa. Berdasarkan hasil penelitian ini, peneliti dapat menyimpulkan bahwa penggunaan media pembelajaran yang sering digunakan guru dan disukai oleh siswa yaitu WhatsApp Group dikarenakan mudah untuk diakses dan tidak membutuhkan banyak kuota untuk mengaksesnya. Namun kendala yang sering dialami siswa saat pembelajaran daring pada masa pandemi yaitu sulit memahami materi pelajaran, belum lagi tugas yang diberikan guru relatif banyak. Oleh karena itu pembelajaran daring ini membuat siswa tidak senang menjalaninya.
\end{abstract}

Kata kunci: Media pembelajaran, Pandemi, Covid-19, WhatsApp

\begin{abstract}
The covid-19 pandemic has changed the order of human life in all aspects of life. The government restricts community activities to prevent crowds from spreading covid-19. Based on Circular Letter No. 15 of 2020 concerning Guidelines for The Implementation of Learning from Home In the Emergency Period of the Spread of Covid-19, the government diverts teaching and learning activities in the classroom or conventional into online or virtual classes. This phenomenon is certainly a new thing experienced by educators and students because they have to use online learning media to connect. The use of online learning media during the covid19 pandemic can be an alternative option to provide a sense of security in teaching and learning. There are many online learning media available such as Zoom, WhatsApp, Google Classroom, Google Meeting, Edmodo, and others. But teachers must be smart in choosing the right learning media according to their designation by considering the readiness and condition of students. Based on the results of this study, researchers can conclude that the use of learning media that is often used by teachers and liked by students is WhatApps Group because it is easy to access and does not require much quota to access it. But the obstacles that students often experience when learning online during the pandemic is difficult to understand the subject matter, not to mention the tasks are given by teachers are relatively many. Therefore, this online learning makes students unhappy to live it.
\end{abstract}

Keywords: Learning media, Pandemic, Covid-19, WhatsApp

https://doi.org/. 


\section{PENDAHULUAN}

Dunia pendidikan selalu menarik untuk dibahas karena selalu menyajikan hal-hal kompleks untuk yang unik serta menarik untuk diulas. Salah satunya pendidikan di masa pandemi covid-19 seperti sekarang memberikan tantangan baru bagi dunia pendidikan tentunya. Kita tahu bahwa pandemi virus covid-19 melanda Indonesia sudah lebih dari satu tahun. Sejak diumumkan kasus pertama pada 2 Maret 2020 hingga saat ini 24 Mei 2021 sudah 1.781 .127 orang terkonfirmasi positif, 1.638 .279 orang sembuh dan 49.455 orang meninggal dunia (Satuan Tugas Penanganan COVID-19, 2021). Dari data tersebut menggambarkan bahwa virus COVID-19 ini sangat mematikan dengan penyebarannya begitu cepat melalui kontak fisik langsung. Untuk mencegah penyebaran virus ini pemerintah indonesia memberlakukan pembatasan aktivitas masyarakat hampir di segala sektor kehidupan. Tentunya ini berdampak terhadap banyak sektor mulai dari sosial, ekonomi bahkan pendidikan.

Begitu juga pelaksanaan pendidikan di masa pandemi. Sektor pendidikan sendiri melalui SE Mendikbud Nomor 4 tahun 2020 tentang pelaksanaan kebijakan pendidikan dalam masa darurat Coronavirus Disease (COVID-19) (Menteri Pendidikan dan Kebudayaan, 2020). Dari surat edaran tersebut mengharuskan siswa, guru, kepala sekolah serta warga sekolah lainnya melakukan kegiatan belajar mengajar dan administrasi secara daring dari rumah. Pasti banyak yang berubah seiring dengan berjalannya waktu.Pelaksanaan pembelajaran daring tentunya berbeda dengan pembelajaran konvensional yang terjadi di kelas, karena pembelajaran daring memisahkan ruang antara siswa dan guru.

Pembelajaran daring merupakan pembelajaran yang dilakukan dengan memanfaat koneksi internet untuk mengakses dan menyalurkan materi belajar (Syarifudin, 2020). Pembelajaran daring lebih fleksibel dari segi ruang dan waktu karena dapat diakses dimanapun dan kapanpun asalkan jaringan internet tersedia dengan baik. Supaya pembelajaran dapat berjalan dengan baik, tentunya memerlukan media pembelajaran yang tepat untuk menghubungkan keduanya secara bersamaan. Media pembelajaran adalah semua bentuk alat komunikasi yang bersifat menyalurkan pesan dari sumber pesan kepada siswa sehingga dapat merangsang pikiran, minat, perasaan dan kemauan siswa dalam melakukan proses pembelajaran (Asmariani, 2016). Oleh karena itu, penggunaan media pembelajaran memiliki peran penting, karena dapat membangkitkan minat dan motivasi belajar siswa jika digunakan dengan benar, sehingga dapat tercapainya tujuan pembelajaran secara efektif dan efisien.

Dengan perkembangan teknologi yang semakin canggih, banyak sekali media pembelajaran daring yang bisa menunjang pembelajaran jarak jauh seperti sekarang. Untuk menunjang pembelajaran daring, tentu pemerintah tidak main-main dalam memberikan dukungan. Berdasarkan arahan dari Presiden, Kemendikbud terus mengembangkan dukungan melalui kerjasama dengan 12 mitra swasta memberikan layanan media pembelajaran gratis untuk dapat diakses oleh pendidik dan peserta didik (Kementerian Pendidikan dan Kebudayaan Republik Indonesia, n.d.). Adapun 12 media pembelajaran daring tersebut yaitu Google For Education, Microsoft office 365, Quipper School, Ruangguru, Rumah Belajar, Icando, IndonesiaX, Meja Kita, Kelas Pintar, Zenius, Cisco Webex, dan Sekolahmu (Adit, 2020). Diluar itu media pembelajaran yang juga bisa digunakan secara gratis ada seperti Zoom, WhatsApp, Google Classroom, Google Meeting , Edmodo, dan lainnya. Dari berbagai media pembelajaran yang ditawarkan tentunya tidak semua akan digunakan oleh guru dan siswa. Oleh karena itu guru harus memilih media yang cocok dan sesuai dengan situasi dan kondisi siswa.

Penggunaan media pembelajaran tentunya akan berdampak pada pemahaman siswa dalam menerima materi ajar yang disampaikan oleh guru (Ekayani, 2017). Dengan penggunaan media pembelajaran yang tetap, tentunya kegiatan belajar mengajar akan 
berjalan dengan efektif dan efisien. Oleh karena itu penelitian kali ini akan membahas tentang penggunaan media pembelajaran daring selama pandemi covid-19.

Beberapa penelitian yang telah dilakukan dengan tema serupa yaitu penggunaan media pembelajaran daring pada masa pandemi covid-19 yaitu: penelitian yang dilakukan oleh Mustakim yang berjudul "Efektivitas Pembelajaran Daring Menggunakan Media Online Selama Pandemi Covid-19 Pada Mata Pelajaran Matematika" pada peserta didik kelas XII MIPA SMA Negeri 1 Wajo menggunakan metode penelitian kuantitatif dengan teknik simple random sampling menyebarkan kuesioner melalui google form. Berdasarkan hasil penelitian tersebut menunjukkan bahwa 23,3\% penggunaan media pembelajaran daring sangat efektif, 46,7\% menilai efektif, $20 \%$ menilai biasa saja, dan $10 \%$ menilai kurang efektif. Tidak hanya itu siswa menganggap bahwa pembelajaran akan lebih efektif apabila pendidik menerangkan materi melakukan belajar menggunakan video conference dengan memberikan pembelajaran yang ringkas namun mudah dipahami. Tidak mengirimkan materi dan tugas yang terlalu memakan kuota, Selain itu dalam pemberian tugas harus sesuai porsinya mengingat mengingat tugas yang diberikan selama pandemi hampir disemua mata pelajaran (Mustakim, 2020).

Penelitian yang dilakukan Baroroh Indiani berjudul "Mengoptimalkan Proses Pembelajaran dengan Media Daring pada Masa Pandemi COVID-19" menyimpulkan bahwa media pembelajaran daring menjadi alternatif bagi pendidik dalam melakukan proses belajar mengajar di tengah pandemi yang sedang berlangsung. Banyak media pembelajaran yang bisa diakses selama pembelajaran daring antara lain telegram, WAG, google classroom, email, zoom dan sebagainya. Tentunya semua media pembelajaran daring mempunyai kelebihan dan kekurangannya masing-masing. Oleh karena itu guru harus dengan selektif memilih media yang akan digunakan sesuai dengan peruntukannya agar pembelajaran berjalan optimal (Indiani, 2020).

Penelitian yang dilakukan Eka Septiani dan Luluk Setyowati yang berjudul "Penggunaan Media Pembelajaran Secara Daring Terhadap Pemahaman Belajar Mahasiswa" pada mahasiswa Prodi Pendidikan Matematika, Universitas Indraprasta PGRI Jakarta menggunakan analisis kualitatif deskriptif dengan metode studi kasus eksplorasi. Hasil penelitian ini menunjukkan bahwa media pembelajaran WAG paling banyak digunakan oleh mahasiswa karena mudah dalam penggunaannya serta tidak membutuhkan banyak kuota untuk mengaksesnya. Namun banyak mahasiswa tidak nyaman selama pembelajaran daring berlangsung (Septiani \& Setyowati, 2020).

\section{METODE PENELITIAN}

Penelitian ini merupakan penelitian kualitatif deskriptif yang memusatkan pada kegiatan ontologis untuk mengumpulkan serta menganalisis data yang telah ditemukan bisa berupa kata, kalimat dan perilaku seseorang yang diamati. Menurut Farida Nugrahani "Penelitian kualitatif desktiptif yaitu Peneliti berusaha menekankan catatan dengan deskripsi kalimat yang rinci, lengkap, mendalam yang menggambarkan situasi yang sebenarnya guna mendukung penyajian data serta peneliti berusaha menganalisis data dalam berbagai nuansa sesuai bentuk aslinya seperti pada waktu dicatat atau dikumpulkan" (Nugrahani \& Hum, 2014). Penggunaan metode kualitatif pada situasi pandemi seperti sekarang bisa dilakukan, peneliti bisa memperoleh data melalui instumen penyebaran kuesioner pada siswa melalui google form. 


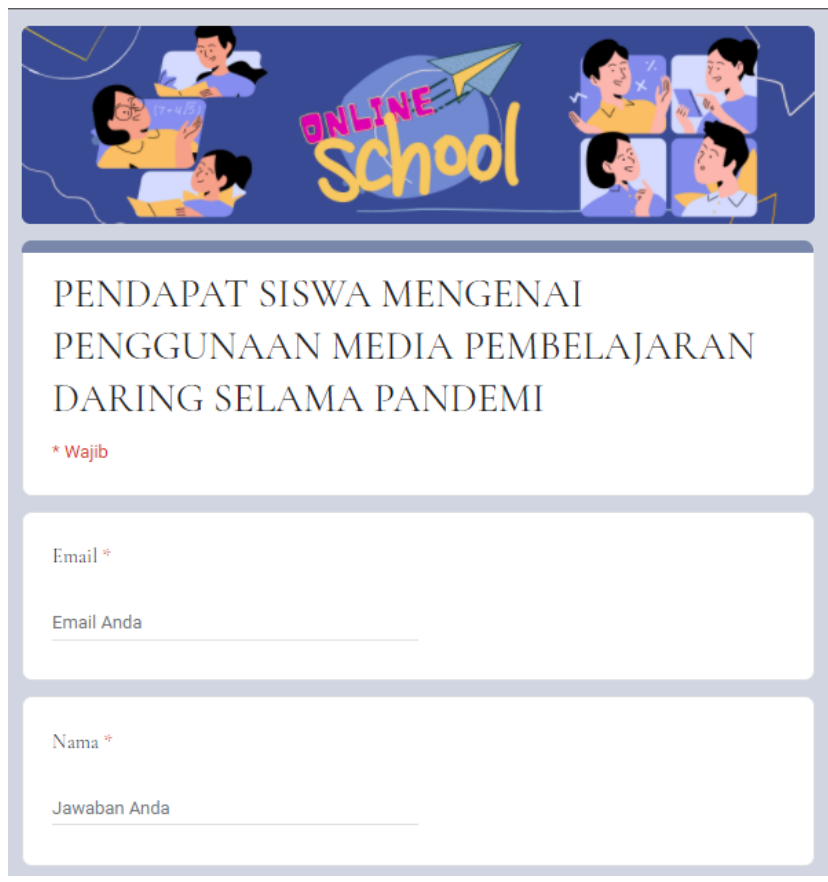

\section{Gambar 1. Kuesioner melalui Google form}

Dengan menggunakan Google form memungkinkan pengumpulan data yang dibutuhkan dengan cara survey online dengan membagikan laman survey kepada responden yang dituju dengan begitu peneliti bisa langsung mengetahui jawaban dari responden yang mengikuti survey (Fitriyani \& Astuti, 2021). Penelitian ini menggunakan pendekatan studi kasus dengan mengumpulkan data menggunakan kuesioner melelui google form berisi pertanyaan seputar bagaimana pendapat siswa mengenai penggunaan media pembelajaran daring pada masa pandemi dengan responden 8 siswa antara kelas 4-6 di SD Negeri 2 Kebondalem kidul, Prambanan. Berikut adalah data respon

Tabel 1. Data Respondem

\begin{tabular}{cc}
\hline Nama & Jenis kelamin \\
\hline Muhammad Asidiq & Laki-laki \\
Rizky Akila & Perempuan \\
Dias Punda Setyawan & Laki-laki \\
Rasyaradityaramadhan & Laki-laki \\
Ratna Seysa Kinanti & Perempuan \\
Riren Aryani Ramadhan & Perempuan \\
Ahnah Irsyad Dallah & Laki-laki \\
Ilham Dwi Saputra & Laki-laki \\
\hline
\end{tabular}

\section{HASIL DAN PEMBAHASAN}

Berdasarkan hasil survey yang telah dilakukan pada siswa kelas 4-6 di SD Negeri 2 Kebondalem kidul, Prambanan, tentang penggunaan media pembelajaran daring pada masa pandemi, menunjukkan:

1. Media pembelajaran daring yang digunakan oleh guru selama masa pandemi yaitu WhatsApp Group sebanyak 87\%.

2. Media pembelajaran daring yang disukai oleh siswa selama masa pandemi yaitu WhatsApp Group sebanyak 37\%.

3. Kendala yang siswa alami selama pembelajaran daring memperlihatkan $50 \%$ siswa sulit memahami materi pelajaran. 
4. Frekuensi pemberian tugas oleh guru selama pembelajaran daring memperlihatkan $63 \%$ menurut siswa banyak.

5. Pendapat siswa tentang pembelajaran daring pada masa pandemi memperlihatkan $37,5 \%$ siswa tidak senang dan kurang senang dengan adanya pembelajaran daring.

Media pembelajaran adalah semua bentuk alat komunikasi yang bersifat menyalurkan pesan dari sumber pesan kepada siswa sehingga dapat merangsang pikiran, minat, perasaan dan kemauan siswa dalam melakukan proses pembelajaran (Asmariani, 2016). Ada banyak jenis media pembelajaran menurut Seels \& Glasgow , media dibagi menjadi dua, yaitu:

1. Media Tradisional yang meliputi media audio, visual, cetak, permainan dan lainnya

2. Media teknologi mutakhir meliputi media berbasis telekomunikasi(jarak jauh), berbasis mikroprosesor seperti media yang digunakan pada pembelajaran daring selama pandemi

Penggunaan media pembelajaran tentunya akan berdampak pada pemahaman siswa dalam menerima materi ajar yang disampaikan oleh guru (Ekayani, 2017). Dengan penggunaan media pembelajaran yang tetap, tentunya kegiatan belajar mengajar akan berjalan dengan efektif dan efisien. Banyak sekali manfaat dari penggunaan media pembelajaran. Menurut Azhar Arsyad manfaat penggunaan media pembelajaran (Nurrita, 2018) yaitu:

1. Media pembelajaran dapat memperjelas penyajian pesan dan informasi sehingga dapat meningkatkan proses serta hasil belajar

2. Media pembelajaran dapat meningkatkan dan mengarahkan perhatian siswa sehingga dapat memunculkan motivasi belajar, interaksi langsung siswa dengan lingkungan sehingga siswa dapat belajar sesuai dengan kemampuan dan minat yang dimiliki.

3. Media pembelajaran dapat mengatasi keterbatasan indra, ruang dan waktu

4. Media pembelajaran dapat memberikan kesamaan pengalaman sehingga kemungkinan terjadi interaksi langsung antara siswa dengan guru, masyarakat dan lingkungan.

Oleh karena itu pemanfaatan media pembelajaran sangat erat kaitannya dengan peningkatan kualitas pembelajaran yang diharapkan. Penggunaan media pembelajaran oleh seorang guru diharapkan dapat menciptakan pengalaman belajar yang lebih bermakna. Dari bebarapa media pembelajaran daring yang dijadikan pilihan seperti WhatsApp Group, Google Classroom, Zoom, Google Meeting dan Edmodo. Media pembelajaran daring pada masa pandemi yang digunakan guru dan disukai siswa yaitu WhatsApp Group. Bisa dilihat pada tabel 2. dan 3.

Tabel 2. Persentase Media Pembelajaran yang digunakan Guru

\begin{tabular}{ccc}
\hline Media Pembelajaran & Banyak Siswa & Persentase \\
\hline WhatsApp Group & 7 & $87 \%$ \\
Google Classroom & 1 & $13 \%$ \\
Zoom & 0 & $0 \%$ \\
Google Meeting & 0 & $0 \%$ \\
Edmodo & 0 & $0 \%$ \\
\hline
\end{tabular}


Tabel 3. Persentase Media Pembelajaran yang disukai Siswa

\begin{tabular}{ccc}
\hline Media Pembelajaran & Banyak Siswa & Persentase \\
\hline WhatsApp Group & 3 & $37 \%$ \\
Google Classroom & 1 & $13 \%$ \\
Zoom & 2 & $25 \%$ \\
Google Meeting & 2 & $25 \%$ \\
Edmodo & 0 & $0 \%$ \\
\hline
\end{tabular}

WhatsApp Group merupakan salah satu fitur yang ada di WhatsApp. WhatsApp sendiri merupakan media bertukar pesan melalui smartphone yang bisa dikoneksikan ke laptop melalui WhatsApp web dengan koneksi internet. Media ini diciptakan oleh Ian Koum pada tahun 2009 dan sekarang sudah digunakan di 180 negara dengan jumlah pengguna lebih dari 2 miliar orang yang tersebar di seluruh dunia (WhatsApp LLC, 2021). Media ini mempermudah kita untuk bertukar pesan kepada keluarga, teman, kerabat, dimanapun dan kapanpun. Bertukar pesan melalui WhatsApp bisa melalui teks, foto, audio, video, dokumen, lokasi, panggilan suara dan panggilan video. Salah satu pemanfaatan WhatsApp dalam pembelajaran daring pada masa pandemi dengan menggunakan WhatsApp Group oleh guru. WhatsApp Group bisa menjadi alternatif media pembelajaran daring yang digunakan oleh guru dan siswa pada masa pandemi dengan memanfaatkan WhatsApp Group sebagai ruang belajar daring untuk memberikan dan menjelaskan materi pelajaran bahkan diskusi kelas. Semuanya bisa dilakukan di WhatsApp Group.

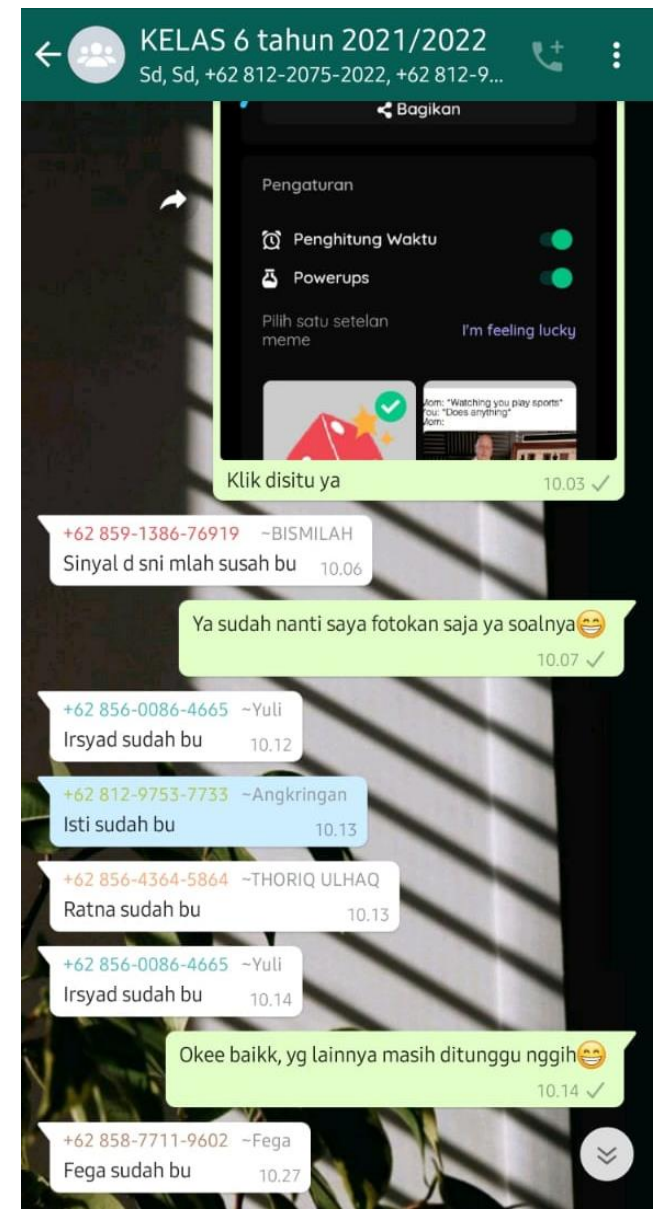

Gambar 2. Salah Satu WhatsApp Group yang digunakan sebagai Media Pembelajaran Daring Selama Pandemi 
Tentunya segala sesuatu pasti ada kelebihan dan kekurangannya, begitu juga WhatsApp memiliki kelebihannya dan kekurangan (Pustikayasa, 2019) yaitu:

1. Mudah diakses oleh semua orang melalui ponsel atau laptop yang terhubung dengan ponsel.

2. Penggunaan WhatsApp tidak membutuhkan banyak kuota untuk mengaksesnya.

3. Guru dapat mengirim materi pembelajaran berupa dokumen, video, audio yang dapat diakses oleh seluruh siswa.

4. Diskusi kelas bisa dilakukan di WhatsApp Group melalui pesan teks atau pesan audio

5. Jika guru mengirimkan pesan, maka guru bisa dengan mudah mengetahui siapa saja yang sudah melihat pesan dan mana yang belum.

6. Penggunaan media WhatsApp Group bisa memudahkan komunikasi antara guru dan siswa selama pandemi virus corona.

Adapun kekurangannya yaitu

1. Jika guru mengirimkan materi pelajaran dengan ukuran yang cukup besar maka akan menyulitkan siswa untuk mengunduh materi.

2. WhatsApp sering meminta update.

3. Banyak pesan yang masuk bisa mengakibatkan ponsel menjadi lambat.

Pembelajaran daring tentunya menjadi tantangan sendiri bagi guru dan siswa karena pembelajaran daring berbeda jauh dari pembelajaran tatap muka di kelas. Pembelajaran daring bisa terlaksana dengan efektif dan efisien apabila guru dan siswa sama-sama aktif dalam pembelajaran yang sedang berlangsung. Namun ada banyak kendala dalam pelaksanaan pembelajaran daring seperti pada tabel 4 .

Tabel 4. Persentase Kendala yang Siswa Alami Selama Pembelajaran Daring

\begin{tabular}{ccc}
\hline Media Pembelajaran & Banyak Siswa & Persentase \\
\hline Jaringan internet & 3 & $37 \%$ \\
Perangkat kurang memadai & 1 & $13 \%$ \\
Mudah bosan & 0 & $0 \%$ \\
Sulit memahami materi pelajaran & 4 & $50 \%$ \\
Banyaknya tugas & 0 & $0 \%$ \\
\hline
\end{tabular}

Dari kendala jaringan internet, perangkat kurang memadai, mudah bosan, sulit memahami materi pelajaran, dan banyak tugas. Salah satu kendala yang paling banyak banyak dipilih siswa dalam pembelajaran daring yaitu $50 \%$ siswa memilih sulitnya memahami materi pelajaran. Hal ini bukan tanpa alasan, bisa terjadi apabila guru hanya mengirim materi pelajaran tanpa menerangkan materi yang diberikan, maka siswa akan kesulitan memahami sendiri maksud dari materi yang diberikan. Oleh karena itu guru harus pintar-pintar menyampaikan materi saat pembelajaran daring agar siswa bisa mengerti dan memahami materi yang diajarkan. Salah satunya dengan memberikan video penjelasan materi dan diakhir pembelajaran bisa memberikan sesi tanya jawab atau diskusi terkait materi yang diberikan, guru bisa memberikan arahan agar siswa lebih aktif dalam berdiskusi dengan guru maupun teman (Ginting et al., 2021). Dengan begitu siswa bisa menanyakan beberapa hal yang belum dimengerti dan dipahami.

Selama pandemi berlangsung, tugas yang diberikan guru juga berbeda dengan pembelajaran tatap muka. Hal ini bisa dilihat pada tabel 5. 
Tabel 5. Persentase Pemberian Tugas oleh Guru Selama Pembelajaran Daring

\begin{tabular}{ccc}
\hline Media Pembelajaran & Banyak Siswa & Persentase \\
\hline Sangat Banyak & 1 & $12 \%$ \\
Banyak & 5 & $63 \%$ \\
Sedikit & 2 & $25 \%$ \\
\hline
\end{tabular}

Frekuensi pemberian tugas yang oleh guru lumayan banyak selama pembelajaran daring berlangsung, hampir di setiap pelajaran memberikan tugas setiap minggunya. Tujuannya baik agar siswa mengisi waktu luangnya dengan belajar hal baru. Tentunya ini berbeda dengan persepsi siswa, dalam menjalani pembelajaran daring akan membuat siswa tidak senang dalam menjalaninya karena bisa menimbulkan stres karena tidak ada waktu bermain dan berkumpul dengan keluarga apalagi di masa seperti sekarang tidak bisa berkumpul dengan teman-teman sebaya. Terbukti dengan presentasi perasaan siswa mengenai pembelajaran daring seperti pada tabel 6.

Tabel 6. Persentase Perasaan Siswa Mengenai Pembelajaran Daring

\begin{tabular}{ccc}
\hline Media Pembelajaran & Banyak Siswa & Persentase \\
\hline Sangat Senang & 1 & $12,5 \%$ \\
Senang & 0 & $0 \%$ \\
Kurang senang & 3 & $37,5 \%$ \\
Tidak Senang & 3 & $37,5 \%$ \\
Sangat tidak Senang & 1 & $12,5 \%$ \\
\hline
\end{tabular}

Kurang senang dan tidak senang mendapatkan presentasi yang sama 37,5 \%. Hal ini terjadi bukan tanpa alasan. Selama pembelajaran daring berlangsung ruang gerak siswa dibatasi dan tidak bisa bermain dengan teman sebaya. Oleh karena itu guru harus mengetahui keadaan siswa dan bisa memotivasi agar siswa bisa semangat menjalani pembelajaran daring. Salah satunya dengan memberikan pengetahuan tentang manajemen waktu dan mengelola stress supa siswa dapat menghindari kejenuhan dalam pelaksanaan pembelajaran daring selama pandemi (Ginting et al., 2021). Selain itu perlunya membangun hubungan antara orang tua siswa dengan guru dan stakeholder secara berkelanjutan, agar bisa memonitoring kegiatan anak selama pembelajaran daring dari rumah (Prasetyo \& Zulela, 2021).

\section{KESIMPULAN}

Penggunaan media pembelajaran yang sering digunakan guru yaitu WhatsApp Group dengan perolehan 87\%, ternyata juga disukai oleh siswa dengan perolehan 37\%. Hal ini dikarenakan WhatsApp Group mudah untuk digunakan dan diakses serta tidak membutuhkan banyak kuota untuk mengaksesnya. Namun kendala yang sering dialami siswa saat pembelajaran daring pada masa pandemi yaitu 50\% siswa kesulitan memahami materi pelajaran, belum lagi tugas yang diberikan guru relatif banyak. Oleh karena itu pembelajaran daring ini membuat 37,5\% siswa tidak senang dan kurang senang dalam menjalani pembelajaran daring.

\section{REFERENSI}

Adit, A. (2020). 12 Aplikasi Pembelajaran Daring Kerjasama Kemendikbud, Gratis! Kompas.Com. https://edukasi.kompas.com/read/2020/03/22/123204571/12aplikasi-pembelajaran-daring-kerjasama-kemendikbud-gratis?page=all Asmariani, A. (2016). KONSEP MEDIA PEMBELAJARAN PAUD. Al-Afkar : Jurnal Keislaman \& Peradaban. https://doi.org/10.28944/afkar.v5i1.108

Ekayani, P. (2017). (2017). Pentingnya Penggunaan Media. Jurnal Fakultas Ilmu 
Pendidikan Universitas Pendidikan Ganesha Singaraja, March. https://www.researchgate.net/publication/315105651

Fitriyani, H., \& Astuti, D. (2021). Pelatihan Pengembangan Instrumen Evaluasi Online menggunakan Google Form bagi Guru Sekolah Dasar/Madrasah Ibtidaiyah. ETHOS: Jurnal Penelitian Dan Pengabdian Kepada Masyarakat, 9(2).

Ginting, E. S., Lubis, T. W. H., \& Pertiwi, S. (2021). Kiat Menghadapi Tantangan Pembelajaran Daring Di Masa Pandemi Covid-19. TRIDARMA: Pengabdian Kepada Masyarakat (PkM), 4(1), 35-43.

Kementerian Pendidikan dan Kebudayaan Republik Indonesia. (n.d.). Laksanakan Arahan Presiden, Kemendikbud Terus Galang Dukungan Pengembang Pembelajaran Daring. Www.Kemdikbud.Go.Id. Retrieved May 25, 2021, from https://www.kemdikbud.go.id/main/blog/2020/03/laksanakan-arahan-presidenkemendikbud-terus-galang-dukungan-pengembang-pembelajaran-daring

Menteri Pendidikan dan Kebudayaan. (2020). SE Mendikbud: Pelaksanaan Kebijakan Pendidikan dalam Masa Darurat Penyebaran Covid-19. Mendikbud RI.

Nugrahani, F., \& Hum, M. (2014). Metode penelitian kualitatif. Solo: Cakra Books.

Nurrita, T. (2018). Pengembangan media pembelajaran untuk meningkatkan hasil belajar siswa. MISYKAT: Jurnal Ilmu-Ilmu Al-Quran, Hadist, Syari'ah Dan Tarbiyah, 3(1), 171.

Prasetyo, T., \& Zulela, M. S. (2021). Proses Pembelajaran Daring Guru Menggunakan Aplikasi Whatsapp Selama Pandemik Covid-19. Jurnal Elementaria Edukasia, 4(1), 138-150.

Pustikayasa, I. M. (2019). Grup whatsapp sebagai media pembelajaran. Widya Genitri: Jurnal Ilmiah Pendidikan, Agama Dan Kebudayaan Hindu, 10(2), 53-62.

Satuan Tugas Penanganan COVID-19. (2021). Peta Sebaran COVID-19. Covid19.Go.Id. https://covid19.go.id/peta-sebaran-covid19

Suttrisno, S. (2021). PENGARUH PEMANFAATAN ALAT PERAGA IPS TERHADAP KINERJA GURU SEKOLAH DASAR. Jurnal Ilmiah Pendidikan Dasar, 8(1), 77-90.

WhatsApp LLC. (2021). Tentang WhatsApp. https://www.whatsapp.com/about/ 